\title{
"The impact of strategic human resources planning on the organizational performance of public shareholding companies in Jordan"
}

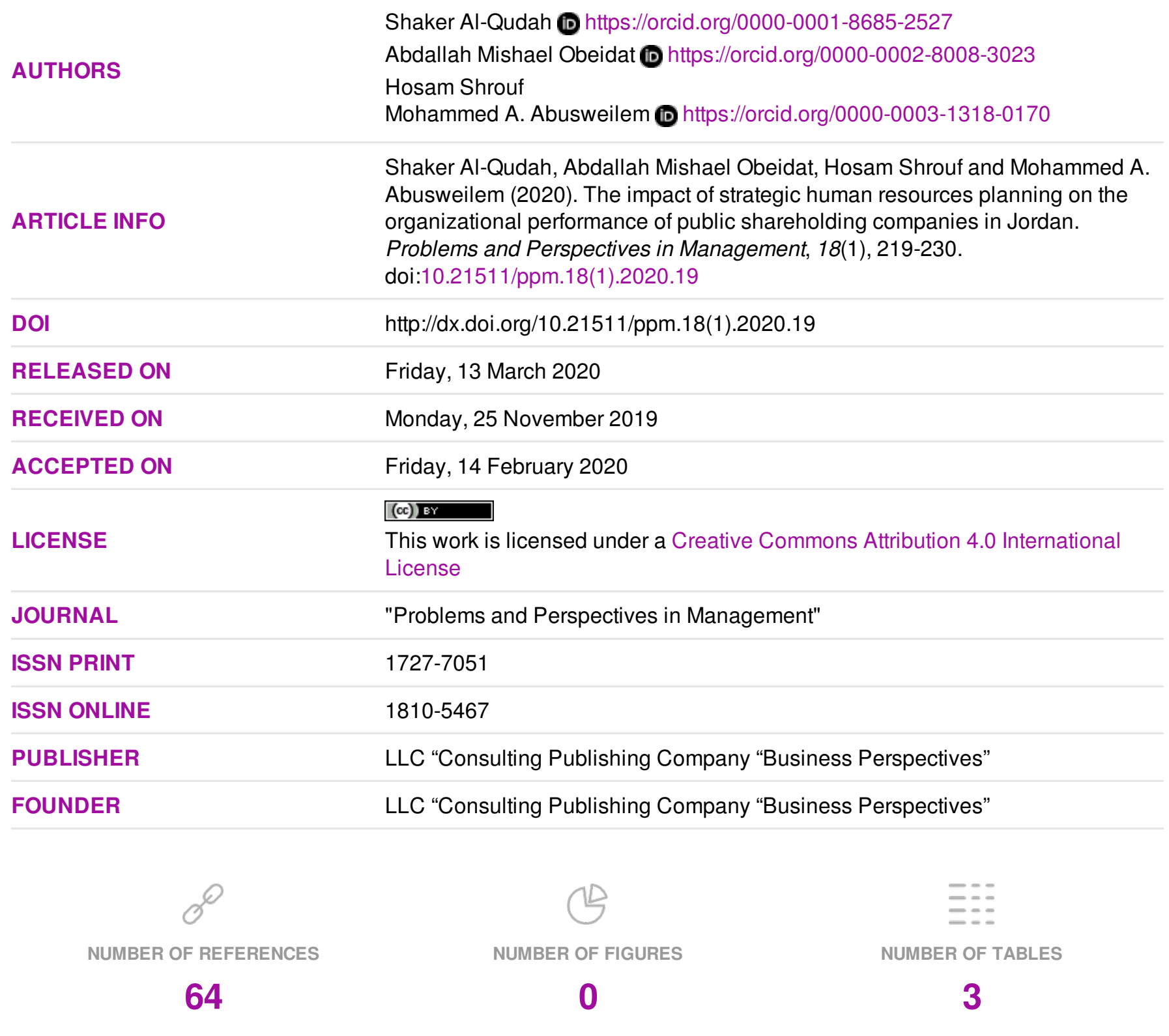

(c) The author(s) 2023. This publication is an open access article. 


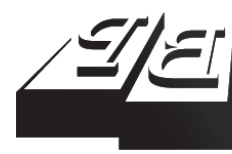

\section{BUSINESS PERSPECTIVES}

LLC "CPC "Business Perspectives" Hryhorii Skovoroda lane, 10, Sumy, 40022, Ukraine www.businessperspectives.org

Received on: $25^{\text {th }}$ of November, 2019 Accepted on: $14^{\text {th }}$ of February, 2020 Published on: $13^{\text {th }}$ of March, 2020

(C) Shaker Al-Qudah, Abdallah Mishael Obeidat, Hosam Shrouf, Mohammed A. Abusweilem, 2020

Shaker Al-Qudah, Ph.D., Assistant Professor, Department of Business Administration, Faculty of Business, Applied Science Private University, Amman, Jordan. (Corresponding author)

Abdallah Mishael Obeidat, Ph.D. Assistant Professor, Department of Business Administration, Economic and Business Collage, Jadara University, Jordan.

Hosam Shrouf, Ph.D., Assistant Professor, Department of Business Administration, Faculty of Business, Applied Science Private University, Amman, Jordan.

Mohammed A. Abusweilem, Ph.D. Assistant Professor, Faculty of Business, College of Business Administration, American University in the Emirates, United Arab Emirates.
Shaker Al-Qudah (Jordan), Abdallah Mishael Obeidat (Jordan),

Hosam Shrouf (Jordan), Mohammed A. Abusweilem (United Arab Emirates)

\begin{abstract}
Performance management (PM) is a common practice used by organizations to assess and manage employees' work. Much of PM research is closely related to management practices. Corporations in the public and nonprofit sector continuously develop PM programs to ensure the sustainability of their organizations.

The study aims to analyze the impact of strategic human resources planning on the organizational performance of Jordanian public shareholding companies for senior management and functional unit managers (human resources, marketing, finance, and accounting). The researchers surveyed all the public shareholding companies registered with the Jordan Securities Commission (JSC) in 2019, wherein they found that only 60 companies applied strategic planning and human resources planning (HRP) together. Two hundred and twenty questionnaires were distributed in 52 companies surveyed, and 203 were adopted for statistical analysis. Several statistical methods were used, most notably the multiple regression analysis. The researchers found out a statistically significant impact of the strategic human resources planning (integration of HRP and strategic planning; strategic participation) on organizational performance. The results showed that adopting the strategic HRP dimensions leads to an increase in an organization's overall productivity, employee satisfaction and reputation, as well as reduced operating costs. HR managers must understand the effectiveness of strategically designed HR practices across functions.
\end{abstract}

\section{Keywords}

JEL Classification

\section{INTRODUCTION}

In light of the increasing number of organizations and the complexity of businesses, the twenty-first century is witnessing fierce global competition, as well as interconnected, complicated, and dynamic environmental forces and influences that make it inevitable to avoid threats and seize opportunities. It is imperative for business organizations to move from traditional thinking and traditional management to strategic thinking and strategic management to manage their internal resources and, concurrently, their external environment (Wheelen \& Hunger, 2008). Strategic planning is the core of the strategic management process and a managerial tool that enables organizations to deal with future events efficiently and effectively, providing them with greater control over their resources and environmental change response (Floris \& Yilmaz, 2010). Organizations have shifted as the 
traditional role of personnel management has become the role of strategic human resources (HR) management, strategic partnering, and, finally, strategic planning process for an entire organization (Al-Omaria, Alomaria, \& Aljawarneha, 2019). Moreover, Price (2009) revealed that while most organizations realize the benefits of strategic planning, only about half are satisfied with the existing processes used. Researchers have concluded that it takes a highly engaged workforce to achieve success in meeting organizational goals (Dunn, 2014). HR staff performance significantly contributes to the overall measurements of HR effectiveness. Leaders are accountable for making outsourcing decisions and considering operating costs a primary reason for implementing outsourcing strategies (Hanafizadeh \& Ravasan, 2017). An organization's mission, vision, and goals are foundational to its organizational performance, and when these guiding principles are shared at every level on the organizational ladder, they will be embraced by an engaged workforce. Thus, organizational alignment is established that will generate the possibility of optimizing organizational performance. Hence, this study aims to identify the impact of the strategic HR planning on the performance of public shareholding companies in Jordan.

This study's importance is related to the importance of both strategic planning and human resources planning (HRP) as prerequisites for organizations' success and the achievement of their strategic objectives, especially that of the public sector shareholding companies in Jordan, as this sector plays an important role in influencing the Jordanian economy and contributing to its growth. The research's importance also lies in the fact that it is concerned with examining strategic HRP and its impact on the companies' performance throughout the research. Most studies that have examined this subject have been conducted in the context of Western environments, and most Arab studies focus on analyzing the reality of the application of strategic planning and HRP as two separate topics.

With the trend towards globalization and the growing and intensifying competition, business organizations seek to achieve a sustainable competitive advantage by investing in their capabilities and competencies to differentiate themselves from their competitors. Qualified HR is a source of uniqueness and scarcity (Carpenter \& Sanders, 2009). Leading organizations are, therefore, keen on the strategic planning of their HR, informed and guided by the organization's strategic planning process. It was noted that there is a need for Arab studies in general, and Jordanian in particular, to examine the strategic planning of HR and its impact on organizational performance. The study's purpose can be achieved by answering the stated question: Does the strategic planning of human resources (integration of HRP and strategic planning; strategic participation) affect the performance of public shareholding companies in Jordan?

\section{LITERATURE REVIEW}

\subsection{Strategic human resources planning}

Strategic human resources management (SHRM) is defined as the process of the alignment and integration of HR strategies and an organization's multiple levels of strategies (Othman, 2009). Management thinkers differ in defining SHRM functions (Byars \& Rue, 2006; Bernardin, 2007; Wattanasupachoke, 2009). The growing importance of people for organizational performance was found to be consistent with emerging of strategic human resources management (SHRM) as a global area of research (Hartel, Fujimoto, Strybosch, \& Fitzpatrick, 2007). HRP comes first, followed by employment, HR development, compensation and benefits, performance appraisal, occupational safety and health, labor relations, and HR research. According to Boon et al. (2018), one of the key objectives of strategic HRP is to enable staff to help their organization achieve its strategic objectives.

Kinikci and Williams (2006) identified HRP as the process of developing a comprehensive strategy to identify an organization's HR needs and forecast future needs. Greer and Plunkett (2007) see it as an important input to the strategic plan- 
ning process and consistent with it. HRP contributes to the achievement of a range of benefits for an organization. Human resources management (HRM) planning and the execution of strategic management leads to improved human capacity, as there is an important and positive relationship between HRM planning and organizational performance and workforce planning and organizational performance (Abdallah \& Phan, 2007; AlFrijawy, 2019). HRP also helps in allocating HR to the organization's activities, controlling costs, and building the base of other HR plans and strategies, such as selection, recruitment, training, performance appraisal, and compensation (Daft, 2008).

Recent trends in the competition have forced business organizations to reconsider not only their plans' content but also the entire planning process to move towards strategic planning (Shehadeh, Al-Zu'bi, Abdallah, \& Maqableh, 2016). Vinces (2007) argues that strategic planning is a process that involves analyzing and shaping systems and strategies, while strategic thinking continues to reflect that process using intuition and creative human-centered thinking at all levels of management and synthesizing them in a way that serves strategic planning. Dess, Lumpkin, and Eisner (2007) recognize the process by which an organization's objectives, policies, and activities are integrated into a coherent plan. Strategic planning is also defined as a process that aims to define an organization's overall objectives and determine how they are to be achieved (Thompson \& Martin, 2010). A futuristic endeavor, strategic planning aims at achieving an orderly transition from a current position to a future position that is more targeted than its value and surpasses its ability to achieve. Dessler, Cole, and Chhinzer (2015) believe that strategic planning enables an organization to control its decisions and resources and forms the foundation for HRP; it provides HRM with the organization's future direction so such efforts can be combined to achieve its strategic objectives.

The literature on strategy and management emphasized that HRP must be related to strategic planning and that the integration of HRP with the strategic planning process leads to a sustainable competitive advantage for an organization (Bagheri, 2016). Schmidt, Willness, Jones, and Bourdage (2018) showed the impact of the differ- entiation of strategic HRM among jobs and found that less investment in the HR system leads to higher turnover and lower organizational citizenship behavior among employees.

Four types of relationships can be identified the strategic planning process and HRP. First is the administrative relationship, which emerges through traditional roles and routines in the practice of strategic planning. Second, comes the oneway relationship, in which HRM responds by supporting strategic plans and programs. The third is the two-way relationship, highlighted through the interrelationships and dependencies between the strategic planning and planning processes of HRM functions. Fourth is the integrative and consensual relationship. This relationship is the first step towards the transition to strategic planning for HR (Teo \& Rodwell, 2003).

Seyedjavdin and Zadek (2009) focused on testing the alignment of HR strategies with those of Coda, César, de Souza Bido, and Louffat (2009) who aimed to identify the reality of the role of SHRM and the impact of its application in both countries. The study found no correlation between strategic planning and strategic HR planning. KaradjovaStoev and Mujtaba (2009) examined the strategic role and engagement of HRM in Disney Europe and its impact on the success of the strategic planning process. The study found that the lack of strategic participation led to the success of the company's strategies in Europe as compared to the United States of America.

\subsection{Organizational performance}

The dominant perception of organizational performance is that it is one of the main concepts in management and very broad, including a wide range of methods developed by experts to describe and measure organizational performance (Abdallah \& Matsui, 2009; G. Lee, S. Lee, Malatesta, \& Fernandez, 2019). There is no agreement between researchers regarding the definition of performance, or this difference is due to the divergent views of thinkers and those interested in this field, and the difference of their objectives is envisaged to formulate a specific definition of this term; some proceeded from the quantitative concept (num- 
bers and proportions), that is, the preference of technical means in loading, while others want to consider the performance of the concept of organizational, social, and economic aspects (Al-Mahasneh, 2013; Abu Nimeh, Abdallah, \& Sweis, 2018). An organization's performance can be defined based on two characteristics: "the ability to maintain profitability and long-term market share" and "competitiveness compared to other organizations." Increasing staff turnover has forced organizations to pay attention to staff commitment as the main focus of strategic organizational alignment (Suifan, Diab, \& Abdallah, 2017).

Performance management (PM) is characterized as a an unending process of determining, evaluating and optimizing the performance of individuals and teams in order to align performance with the organization's strategic objectives (Aguinis, 2013, p. 2). Performance management $(\mathrm{PM})$ refers to an integrated and structured set of guidance systems and employee performance appraisal (Ramataboe \& Lues, 2018). Organizational performance is also interested in the efficiency and effectiveness of the transformational processes at each level of an organization since this reflects the extent to which an organization is accustomed to achieving its goals. There are three levels that analyses focus on in the search for performance: strategic group level, organizational level, and industrial level (Anwar, 2019). Besides, organizational performance is considered a fundamental concept for an organization, ultimate dependent variable, and a widespread phenomenon in all the fields and areas within managerial knowledge (Alrowwad, Obeidat, Tarhini, \& Aqqad, 2017). The differences regarding the performance concept stem from the different criteria and standards adopted in the study of performance and the measurements used by managers and organizations (Al-ma'ani, Al-Qudah, \& Shrouf, 2019). In its simplest form, performance represents the results desired by the organization (Alqutub, 2012; Awad, Al-Zu'bi, \& Abdallah, 2016). One of the most important characteristics of organizational performance is the ability to maintain the stability and continuity of the work through the accumulated experiences and previous experiments that enrich the organiza- tion and to pass these experiences from generation to generation, so the organization is not affected by the absence of or a change in leadership (Abdallah \& Matsui, 2008). According to Wójcik (2015), the focus of future competitive business strategies will depend on the organizational renewal ability inside an organization, especially within HR, where a systematic work analysis can enhance the learning experience and embrace discovered knowledge, as well as drive organizations to revitalize their work and gain significant improvements in performance (Ramanathan \& Sharma, 2017; Saffar \& Obeidat, 2019). HR is an important source for maintaining competitiveness, so little attention was paid to employment levels and their effect on organizational performance in the public sector (Park, 2019). Much literature demonstrates the importance of HRM systems or practices, and different recruitment models have been developed in the private sector literature to evaluate the optimal employment level, according to a management review of functional characteristics and its effect on organizational performance (Siebert \& Zubanov, 2009).

\subsection{Strategic human resources planning (HRP) and organizational performance}

HR is the key element of organizational performance and goal achievement in organizations. Due to the rapid changes and challenges facing organizations, there is an increased need for the strategic planning of HR to help organizations meet these challenges. HRP includes the process of analyzing and identifying the organization's HR needs (Kattab, 2003).

Usual activities include HR programs such as planning, record-keeping, recruiting, selection, training, employee relations, and compensation. Lucier (2009) argues that the HRM process involves planning to attract, develop, and retain employees. Bratton and Gold (2007) define HRP as "a systematic forecasting process associated with the future demand and supply of staff as well as the dissemination of their skills within the strategic objectives of the organization." Werner and DeSimone (2006) state that HRP will help companies predict how changes will 
affect their strategies and HR needs. Planning any company's workforce needs is particularly important, considering the rapid changes in external market requirements. Therefore, the needs of an organization's HR strategy, both quantitative and qualitative, must be balanced against what is available currently and in the future (Bhatia, 2007).

Strategic HRP plays an important role in determining performance and results standards, so it must be compared with the standard, so HR managers can know how their department is moving towards its and the organization's goals. Therefore, HR managers must demonstrate employer return on investment through strategic activities (Sullivan \& Richardson, 2011).

Effective workforce planning helps councils identify and plan how the challenges and priorities of the current and future workforce are addressed. It also gives a sound framework for developing an effective workforce strategy. Further, workforce planning requires the development of strategies to meet these requirements, which includes identifying future actions to attract and retain the appropriate number and type of workers needed by the organization (Sloan, 2010).

When planning for investment in HR development and performance, HR staff should refer to the approved workforce planning strategy to gain more information about the expected growth in the workforce, or whether staff career development opportunities are limited. Thus, the organization should pursue strategies aimed at retaining employees, especially if the company is experiencing slow growth. For evaluations, staff performance appraisal is conducted in a practical context related to its theme plan, which forms the scientific basis for the organization's daily work.

\section{RESEARCH METHODOLOGY}

\subsection{Research model and hypotheses development}

This study analyzes the impact of the strategic planning of HR, integration of HRP, and strategic participation on the performance of public share- holding companies in Jordan. Garavan (2007) indicates that there is now a recognized trend of well-chosen HR development practices with a direct effect on both individual and organizational performance. HR should play a serious leadership role in fostering the development of HR as support for organizational development. This will allow HR to shift from a process-oriented and operational approach to a strategic one (Gold, 2011). For organizations to be competitive in both the public and private sectors, effective management HR methods are needed to successfully implement their organizational strategies and objectives, thus developing their overall performance (Sthapit, 2008).

H1: There is a positive impact of strategic human resources planning (integration of HRP and strategic planning) on the organizational performance of public shareholding companies in Jordan.

H2: There is a positive impact of strategic HRP (strategic participation) on the organizational performance of public shareholding companies in Jordan.

\subsection{Study sample and procedure}

The current study's population included all the Jordanian shareholding companies registered in the Jordan Securities Commission (JSC) for the year 2019, which numbered 239 companies divided into four sectors (financial, industrial, services, and insurance). A preliminary survey was conducted, in which only 60 (25\%) of the community adopted strategic planning and HRP together. Sixty (60) companies can be considered this study's stratified sample, while eight companies apologized for participating in the study. The analysis and inspection units were comprised of senior management personnel working in the sample of public shareholding companies in Jordan. Who forms the strategic planning team in these companies? The study consists of all levels in senior management, HR, functional and administrative units (marketing, accounting, finance, information systems), and planning, if available. Two hundred and twenty questionnaires were distributed, of which 203 were recovered. Seventeen questionnaires were excluded because of a large 
amount of missing data.The data were obtained through an online survey. The link to the online survey was sent via e-mail to personnel of the mobile companies who were randomly selected and approved for participation. Thus, the number of validated questionnaires (203) comprised $92.2 \%$ of the distributed questionnaires. The sample was selected because it is the largest and most important sector of the economy in terms of activity and the number of employees representing public shareholding companies.

To analyze and test the hypotheses identified by the study, some statistical indicators were adopted using the Statistical Package for Social Sciences (SPSS), wherein the frequency and percentages of the study sample's characteristics were used. The standard deviation was used to determine the extent of the responses' concentration and dispersion to the paragraphs of the study. The $R^{2}$ was used to determine the explanatory ratio of the independent variable's effect on the dependent variable. A regression analysis was used to determine the model's suitability to test the regression between the independent variable (strategic HRP) and the dependent variable (organizational performance). To test the study's hypotheses, multiple regressions were used to test the impact of the independent variable on the dependent variable.

\section{RESEARCH RESULTS}

The findings demonstrated that $83 \%$ of the managers were male, while only $17 \%$ were female. Furthermore, $48 \%$ of the managers were aged from 26 to 34 years, and $27 \%$ were aged from 35 to 41 years, $18 \%$ were aged from 42 to 48 years, whereas only $7 \%$ were aged from 49 to 55 years. Finally, the managers were asked about their qualifications, and the results showed that $52 \%$ were graduates, $30 \%$ were postgraduates, and only $18 \%$ were undergraduates (Table 1). The percentage of those holding scientific university qualifications (bachelor's and graduate) was $70 \%$, which indicates that the public shareholding companies in question are attracting those with scientific university qualifications for leadership positions. Moreover, the postgraduate percentage was 30\% of the respondents.
Table 1. Demographics

\begin{tabular}{l|c|c}
\hline \multicolumn{1}{c}{ Demographics } & N & Percent \\
\hline Male & Gender & \\
\hline Female & 164 & 83 \\
\hline \multicolumn{2}{c}{ Age } & 17 \\
\hline $26-34$ years & 39 & \\
\hline $35-41$ years & 55 & 48 \\
\hline $42-48$ years & 35 & 27 \\
\hline $49-55$ years & 15 & 18 \\
\hline & Qualification & 7 \\
\hline Undergraduate & 35 & 18 \\
\hline Graduate & 105 & 52 \\
Postgraduate & 63 & 30 \\
\hline
\end{tabular}

\subsection{Validity and reliability}

The questionnaire's apparent validity was tested by presenting it to a panel of experienced and competent academic professors who gave their opinions in terms of its clarity, coherence, and validity for collecting data related to the study, as well as any other observations they deemed appropriate concerning correction or deletion, as determined by the arbitrator. The referees' observations and suggestions were considered, and the questionnaire was reviewed and undertaken by the arbitrators who made the appropriate amendments, as a test of the apparent validity of the tool.

The reliability of the tool was used to calculate the variables involved and then evaluated using Cronbach's alpha coefficient, where the outcome of the scale is statistically appropriate if Cronbach's alpha is greater than 0.60 (Sekaran, 2016). The closer the value is to $100 \%$, the higher the study tool's stability. Looking at the data in the following table, the internal coefficient of Cronbach's alpha was measured for the study variables and dimensions and for the study tool as a whole to determine the consistency of responses. Table 2 shows the results of the Cronbach's alpha of the independent and dependent variables: the values of the internal consistency of Cronbach's alpha for the study tool's paragraphs ranged from 0.870 to 0.896 , and therefore, all values are greater than 0.60 . This is an indicator of the study tool's reliability, the consistency between the study tool's paragraphs, and the reliability of statistical analysis. 


\subsection{Descriptive statistics}

Table 2 shows that the overall average of the strategic planning of HR dimensions in terms of relative importance is high, with general average of 4.122 and standard deviation of 0.676 . Strategic participation was ranked first, with average of 4.231, standard deviation of 0.732 , and high relative importance, while the integration of HRP and strategic planning was ranked with average of 4.139 , standard deviation of 0.719 , and high relative importance.

\subsection{Hypotheses testing results}

Multiple regression analysis was used to test the hypotheses.

The results in Table 3 show that the correlation coefficient $(R=0.646)$ shows the relationship between the independent and dependent variables, and the influence of the independent variable (strategic HRP) on the dependent variable (organizational performance) has a statistically significant effect, where the value of $F$ is calculated as 71.548 , and

Table 2. The constructs' measurements: means, standard deviations, and reliability

\begin{tabular}{|c|c|c|c|c|c|}
\hline $\mathbf{Q}$ & Measurement & Mean & SD & Level & C. Alpha \\
\hline 1 & $\begin{array}{l}\text { The company is keen to analyze its internal environment to identify the } \\
\text { strengths and weaknesses of its HR }\end{array}$ & 4.121 & 0.721 & High & \\
\hline 2 & $\begin{array}{l}\text { The company develops its strategies to enhance the importance of the } \\
\text { role of its HR in the success of achieving those strategies }\end{array}$ & 4.021 & 0.874 & High & \\
\hline 3 & $\begin{array}{l}\text { The HR department's planning activities are geared towards achieving } \\
\text { the company's mission }\end{array}$ & 3.399 & 0.456 & High & \\
\hline 4 & $\begin{array}{l}\text { The organization analyzes its external environment to exploit } \\
\text { opportunities and avoid threats associated with its HR }\end{array}$ & 3.985 & 0.851 & High & \\
\hline \multirow[t]{2}{*}{5} & HR plans are adjusted in light of changes in the external environment & 4.345 & 0.743 & High & \\
\hline & Integration of HRP and strategic planning & 4.139 & 0.719 & High & 0.870 \\
\hline 1 & $\begin{array}{l}\text { Information on strategic plans is not available to all staff at all } \\
\text { administrative levels }\end{array}$ & 4.254 & 0.861 & High & \\
\hline 2 & The company's strategic and HRP processes are not synchronized & 4.001 & 0.746 & High & \\
\hline 3 & $\begin{array}{l}\text { The company lacks an effective communication system that supports } \\
\text { the integration of strategic planning and HRP }\end{array}$ & 4.341 & 0.755 & High & \\
\hline 4 & $\begin{array}{l}\text { Information on strategic plans is not available to all staff at all } \\
\text { administrative levels }\end{array}$ & 3.854 & 0.801 & High & \\
\hline 5 & $\begin{array}{l}\text { The company allows employees to submit their suggestions for strategy } \\
\text { development }\end{array}$ & 3.915 & 0.761 & High & \\
\hline \multicolumn{2}{|r|}{ Strategic participation } & 4.231 & 0.732 & High & 0.899 \\
\hline 1 & Strategic HRP helps utilize the company's HR efficiently & 4.654 & 0.783 & High & \\
\hline 2 & Strategic HRP increases the return on investment rate for the company & 4.152 & 0.788 & High & \\
\hline 3 & $\begin{array}{l}\text { Strategic HRP enables the company to increase the rate of return on its } \\
\text { assets }\end{array}$ & 3.854 & 0.645 & High & \\
\hline 4 & Strategic HRP improves the company's competitive position & 3.758 & 0.765 & High & \\
\hline 5 & $\begin{array}{l}\text { The employees' level of performance is in line with internationally } \\
\text { accepted standards }\end{array}$ & 4.362 & 0.689 & High & \\
\hline 6 & $\begin{array}{l}\text { The company always strives to study all complaints and observations } \\
\text { submitted by customers }\end{array}$ & 4.327 & 0.827 & High & \\
\hline 7 & $\begin{array}{l}\text { Training programs in the company are designed to improve the quality of } \\
\text { services provided to beneficiaries }\end{array}$ & 4.415 & 0.546 & High & \\
\hline \multicolumn{2}{|r|}{ Organizational performance } & 4.301 & 0.662 & High & 0.896 \\
\hline
\end{tabular}

Note: Abbreviations: $\mathrm{HR}=$ human resources, $\mathrm{HRP}=$ human resources planning.

Table 3. Hypothesis test results

\begin{tabular}{|c|c|c|c|c|c|c|c|c|c|}
\hline \multirow{4}{*}{$\begin{array}{l}\text { Organizational } \\
\text { performance }\end{array}$} & \multicolumn{2}{|c|}{ Model summary } & \multicolumn{2}{|c|}{ ANOVA } & \multicolumn{5}{|c|}{ Coefficients } \\
\hline & $\boldsymbol{R}$ & $R^{2}$ & $\boldsymbol{F}$ & Sig. $F^{*}$ & Independent variable & $B$ & $\begin{array}{l}\text { Std. } \\
\text { error }\end{array}$ & $T$-stat & Sig $t^{*}$ \\
\hline & \multirow[t]{2}{*}{0.646} & \multirow[t]{2}{*}{0.398} & \multirow[t]{2}{*}{71.548} & \multirow[t]{2}{*}{0.000} & $\begin{array}{l}\text { Integration of human resources planning } \\
\text { and strategic planning }\end{array}$ & 0.380 & 0.044 & 0.815 & 0.002 \\
\hline & & & & & Strategic participation & 0.398 & 0.039 & 9.944 & 0.000 \\
\hline
\end{tabular}

Note: $*$ The effect is statistically significant at $(\alpha \leq 0.05)$ level. 
the significance level $(\mathrm{Sig}=0.000)$ is less than 0.05 , and where the coefficient of determination value is $R^{2}=0.398$. This indicates that the variance can explain $39.8 \%$ of the variance in organizational performance in strategic HRP combined.

While the coefficient table showed that the value of $B$ for the integration of the HRP and strategic planning dimensions was 0.380 , the value of $t$ was 8.815 , and the level of significance was $\operatorname{Sig}=0.002$, which indicates that this dimension's effect is significant. The value of $\mathrm{B}$ for the strategic participation dimension was 0.398 , the value of $t$ was 9.944 , and the level of significance was $\mathrm{Sig}=0.000$, which indicates that this dimension's effect is significant.

\section{DISCUSSION}

Täks and Vadi (2019) argue that the main actors of strategic planning are owners top and managers of the middle level. Middle-level managers have a crucial role in involving the company's low-level management in strategic planning. When owners are involved in strategic planning, companies tend to use external management tools, such as customer relationship management. The participation of top managers is related to internally oriented management tools, most likely with the reengineering of business processes. In the case of top managers' and owners' simulta- neous participation, it is better to use owner-related management tools. Mid-level managers are often involved in strategic planning while doing benchmarking, while top managers are involved when reengineering is used in the business process. Bayesian network models often involved the experts and blue-collar workers as participants, while those networks did not show any interaction between strategic managers and management tools.

Adopting the dimensions of strategic HRP leads to an increase in an organization's overall productivity, employee satisfaction and reputation, as well as reduced operating costs. Organizations do their best to adapt to changes they face to improve performance and maintain competitiveness (Masa'deh, Obeidat, \& Tarhini, 2016), but they must use their HR effectively to engage them in their work. Hence, HR managers must understand the effectiveness of strategically designed HR practices across functions such as training, planning, reward, recruitment, and selection in fostering a culture of employee engagement in the organization (Indulekha, Vineeth, \& Gayathri, 2019). SHRM is used to link HRM explicitly to address an organization's strategic management processes and emphasize coordination or alignment between different HRM practices (Indulekha, Vineeth, \& Gayathri, 2019).

\section{CONCLUSION}

This research was designed to identify the effect of strategic HRP on the performance of Jordanian public shareholding companies in the managers' opinion, where two hypotheses were built, and the results of the hypotheses test were as follows: first, there is a statistically significant effect of the integration of HRP and strategic planning on the organizational performance. The results were consistent with those of Nwachukwu and Chladkova (2019), whose study points out that HR, financial resources, and strategic analysis capability are positively and significantly related to strategic performance. Besides, the organizational structure controls the relationship between HR, financial resources, strategic analysis capability, and strategic performance, which means that by recognizing the organizational structure's effect on human and financial resources, and strategic analysis performance, managers and/or executives can significantly improve strategic performance.

Second, the result of the second hypothesis test was due to the presence of a statistically significant effect of strategic participation on the organizational performance of the public shareholding companies in Jordan, where this result follows the results of the research of the study of Kasule and Bisaso (2019), which indicated that strategic HRM practices were barely practiced at Uganda's public universities. The findings also revealed that top and mid-level managers are strongly committed to the integration of 
strategic HRM practices, which can mitigate the ineffective management at Uganda's public universities. The paper concludes that because of the quick changes caused by globalization, the knowledge-based economy, the technological revolution, and the decline in findings for higher education from governments, public universities in Uganda must adopt SHRM to improve their efficiency.

Strategic management links the organization to a common sense of purpose. It is often responsible for improving financial performance. Besides, it gives specific objectives and instructions to the organization and promotes continuity in decision-making. It also promotes change in the organization to address dynamic situations (Bisharat, Obeidat, Tarhini, \& Mukattash, 2016; Malkawi, Baniata, \& Obeidat, 2017).

\section{IMPLICATIONS AND FUTURE RESEARCH}

This study investigated the impact of strategic HRP on the performance of public shareholding companies in Jordan, as these companies are a vital artery in the Jordanian economy that needs efficient HR. This study's main result showed an impact of strategic HRP on the organizational performance of the public shareholding companies in Jordan. These companies must remain vigilant in securing and preserving their HR. Companies in Jordan should maintain the implementation of strategic HRP and the current state of consensus and work to develop them continuously by enhancing and maximizing the consensus potential in such areas as strategic engagement, transparency, and access to and exchange of information. Researchers recommend conducting development and training programs for workers at all administrative levels to keep pace with international companies' continuous development. Further, the Jordanian companies must contribute to developing modern mechanisms for strategic HRP, such as the establishment of databases that feed strategic planning processes with the necessary data and information. Besides, in terms of public shareholding companies and their creative growth, it is essential to incorporate strategic HRP and to concentrate on all aspects of R\&D, including system and organization and financing and strategy. For future research, it is important to explore why the strategic planning method does not show the desired outcomes for the organization in some scenarios.

\section{AUTHOR CONTRIBUTIONS}

Conceptualization: Shaker Al-Qudah, Abdallah Mishael Obeidat.

Data curation: Shaker Al-Qudah, Abdallah Mishael Obeidat.

Formal analysis: Abdallah Mishael Obeidat.

Funding acquisition: Hosam Shrouf.

Investigation: Shaker Al-Qudah, Hosam Shrouf, Mohammed A. Abusweilem.

Methodology: Shaker Al-Qudah, Abdallah Mishael Obeidat.

Project administration: Shaker Al-Qudah.

Validation: Shaker Al-Qudah, Abdallah Mishael Obeidat, Mohammed A. Abusweilem.

Writing - original draft: Shaker Al-Qudah, Abdallah Mishael Obeidat.

Writing - review \& editing: Mohammed A. Abusweilem.

\section{REFERENCES}

1. Abdallah, A., \& Phan, C. A. (2007). The relationship between just-in-time production and human resource management, and their impact on competitive performance. Yokohama Business Review, 28(2), 27-57. Retrieved from http://www.cba.ynu.ac.jp/

gakkai/kaisi/pdf/28-2-3.pdf

2. Abdallah, A. B., Phan, A. C., \& Matsui, Y. (2009, June). Investigating the relationship between strategic manufacturing goals and mass customization (pp. 1-10). The 16th International Annual European Operations Management Association (EurOMA) Proceedings, Goteborg. Retrieved from https://www.researchgate.net/ 
publication/271530106_Investigating_the_relationship_between_ strategic_manufacturing_goals_ and_mass_customization

3. Abu Nimeh, H., Abdallah, A. B., \& Sweis, R. (2018). Lean supply chain management practices and performance: Empirical evidence from manufacturing companies. International Journal of Supply Chain Management, 7(1), 1-15. Retrieved from https://www.researchgate. net/publication/323454401_ Lean_Supply_Chain_Management_Practices_and_Performance_Empirical_Evidence_. from_Manufacturing_Companies

4. Aguinis, H. (2013). Performance management. Upper Saddle River. NJ: Pearson Prentice Hall.

5. Al-Frijawy, J., Militaru, C., \& Tonoiu, S. (2019). Planning Human Resources Management, Development and Training of Staff, and Their Impact on Organizational Performance, in the Iraq Oil Companies Sector. American Scientific Research Journal for Engineering, Technology, and Sciences (ASRJETS), 55(1), 121-138. Retrieved from https:// www.academia.edu/39276907/ Planning_Human_Resources_ Management_Development_and_ Training_of_Staff_and_Their_Impact_on_Organizational_Performance_in_the_Iraq_Oil_Companies_Sector

6. Al-ma’ani, B., Al-Qudah, S., Shrouf, H. (2019). The Impact of Corporate Social Responsibility on Organizational Performance in Telecommunication Sector in Jordan. Modern Applied Science, Canadian Center of Science and Education, 13(4), 1-11. https://doi. org/10.5539/mas.v13n4p1

7. Al-Mahasneh, I. (2013). Management of Functional Performance Assessment between Theory and Practice. Dar Jarir for Publishing \& Distribution, Amman, Jordan.

8. Al-Omaria, Z. S., Alomaria, K. A. A., \& Aljawarneha, N. M. (2019). The role of empowerment in improving internal process, customer satisfaction, learning and growth. Management Science Letters, 10(4), 841-848. http://dx.doi.org/10.5267/j. msl.2019.10.013

9. Al-Qutob, M. (2012). Strategic choice and its effect on achieving competitive advantage (pp. 42-46). Amman - Jordan: Dar Al-Hamed for Publishing and Distribution.

10. Alrowwad, A. A., Obeidat, B. Y., Tarhini, A., \& Aqqad, N. (2017). The impact of transformational leadership on organizational performance via the mediating role of corporate social responsibility: A structural equation modeling approach. International Business Research, 10(1), 199-221. Retrieved from https://ideas.repec.org/a/ibn/ ibrjnl/v10y2017ilp199-221.html

11. Anwar, J. (2019). Business strategy and organizational performance: measures and relationships (Doctoral dissertation). Islamabad: COMSATS Institute of Information Technology.

12. Awad, H., Al-Zu'bi, Z. M. F., \& Abdallah, A. B. (2016). A quantitative analysis of the causes of drug shortages in Jordan: a supply chain perspective. International Business Research, 9(6), 53-63. Retrieved from https://www.researchgate.net/ publication/299503037_A_Quantitative_Analysis_of_the_Causes_ of_Drug_Shortages_in_Jordan_A_ Supply_Chain_Perspective

13. Bagheri, J. (2016). Overlaps between human resources' strategic planning and strategic management tools in public organizations. Procedia-Social and Behavioral Sciences, 230, 430-438. https://doi.org/10.1016/j.sbspro.2016.09.054

14. Bernardin, H. J. (2007). Human Resource Management: An Experiential Approach (4th ed.). Boston: Irwin McGraw Hill.

15. Bhatia, S. K. (2007). Strategic Human Resource Management: winning through people. Deep \& Deep Publications PVT. LTD. New Delhi, India.

16. Bisharat, H., Obeidat, B. Y., Tarhini, A., \& Mukattash, I.
(2016). The Effect of Human Resource Management Practices on Organizational Commitment in Chain Pharmacies in Jordan. International Journal of Business and Management, 12(1), 50. Retrieved from https://www.researchgate.net/ publication/311959699_The_Effect_of_Human_Resource_Management_Practices_on_Organizational_Commitment_in_Chain_ Pharmacies_in_Jordan

17. Boon, C., Eckardt, R., Lepak, D. P., \& Boselie, P. (2018). Integrating strategic human capital and strategic human resource management. International Journal of Human Resource Management, 29(1), 34-67. https:// doi.org/10.1080/09585192.2017.1 380063

18. Bratton, J., \& Gold, J. (2007). Human resource management: theory and practice (4th ed.). Houndmills: Macmillan.

19. Byars, L. L., \& Rue, L. W. (2006). Human Resource Management (8th ed.). Boston: McGraw Hill Irwin.

20. Carpenter, M. A., \& Sanders, Wm. G. (2009). Strategic Management: A Dynamic Perspective. Pearson Prentice Hall. Upper Saddle River, New Jersey.

21. Coda, R., César, A. M. R. V. C., de Souza Bido, D., \& Louffat, E. (2009). Strategic Hr? A Study of the Perceived Role of HRM Departments in Brazil and Peru. Brazilian Administration Review, 6(1), 15-33. https:// doi.org/10.1590/S180776922009000100003

22. Daft, R. L. (2008). New Era of Management (2nd ed.). Australia: Thomson South-Western.

23. Dess, G. G., Lumpkin, G. T., \& Eisner, A. B. (2007). Strategic Management: Texts and Cases (3rd ed.). Boston: Irwin Mc Graw-Hill.

24. Dessler, G., Cole, N. D., \& Chhinzer, N. (2015). Management of human resources: The essentials. Pearson. Retrieved from https:// www.amazon.com/ManagementHuman-Resources-EssentialsCanadian/dp/0132114909 
25. Dunn, L. (2014). Why culture trumps strategy. Becker's Hospital Review. Retrieved from https:// www.beckershospitalreview.com/ healthcare-blog/why-culturetrumps-strategy.html

26. Flouris, T., \& Yilmaz, A. (2010). The Risk Management Framework to Strategic Human Resource Management. International Research Journal of Finance and Economics, 36, 25-45. Retrieved from https://www.strimgroup. com/wp-content/uploads/pdf/ RiskMgmtFramework_to_StrategicHRM.pdf

27. Garavan, T. N. (2007). A Strategic Perspective on Human Resource Development Advances. Developing Human Resources, 9(1), 11-30. https://doi.org /10.1177\%2F1523422306294492

28. Gold, J., Walton, J., Cureton, P., \& Anderson, L. (2011). Theorising and practitioners in HRD. The role of adductive reasoning. Journal of European Industrial Training, 35(3), 230-246. Retrieved from https:// eric.ed.gov/?id=EJ922417

29. Greer, C. R., \& Plunkett, R. W. (2007). Supervisory Management (11th ed.). Upper Saddle River, New Jersey: PEARSON Prentice Hall.

30. Hanafizadeh, P., \& Ravasan, A. Z. (2017). An investigation into the factors influencing the outsourcing decision of e-banking services: A multi-perspective framework. Journal of Global Operations and Strategic Sourcing, 10, 67-89. https://doi.org/10.1108/ JGOSS-05-2016-0016

31. Hartel, C., Fujimoto, Y., Strybosch, V. E., \& Fitzpatrick, K. (2007). Human Resource Management: Transforming Theory into Iinnovative Practice. Pearson Education Australia.

32. Indulekha, K., Vineeth, K. M., \& Gayathri, J. (2019). Strategic human resource practices and employee engagement: a theoretical perspective. Adalya Journal, 8(9), 161-169. Retrieved from https://www.researchgate.net/profile/Gayathri_J/ publication/335834783_STRATEGIC_HUMAN_RE-
SOURCE_PRACTICES_AND_ EMPLOYEE_ENGAGEMENT_A_ THEORETICAL_PERSPECTIVE/ links/5d7f51d392851c87c38b362e/ STRATEGIC-HUMAN-RESOURCE-PRACTICES-ANDEMPLOYEE-ENGAGEMENT-ATHEORETICAL-PERSPECTIVE. pdf

33. Karadjova-Stoev, G., \& Mujtaba, B. G. (2016). Strategic human resource management and global expansion lessons from the Euro Disney challenges in France. International Business \& Economics Research Journal, 15(3), 69-78. https://doi.org/10.19030/iber. v15i3.9672

34. Kasule, G. W., \& Bisaso, R. (2019). Integration of strategic human resource management for efficiency in Uganda public universities. West East Journal of Social Sciences, 8, 122-132. Retrieved from https://www. researchgate.net/publication/338088329_Integration_Of_ Strategic_Human_Resource_Management_For_Efficiency_In_Uganda_Public_Universities

35. Khattab, A. S. (2003). Strategic Management of Human Resources. Hariri Printing House

36. Kinicki, A., \& Williams, B. K. (2006). Management: A Practical Introduction (2nd ed.). Boston: Mc Graw Hill Irwin.

37. Lee, G. R., Lee, S., Malatesta, D., \& Fernandez, S. (2019). Outsourcing and Organizational Performance: The Employee Perspective. American Review of Public Administration. https://doi.org /10.1177\%2F0275074019855469

38. Malkawi, D. N. M., Baniata, D. M. I., \& Obeidat, D. A. M. (2017). The Impact of E-Government Applications on Decision-Making Effectiveness: Case Study at Jordanian Ministry of InteriorJordan. International Review of Management and Business Research, 6(1), 172. Retrieved from https://www.researchgate.net/ publication/335354761_The_Impact_of_E-government_Applications_on_Decision-_Making_Effectiveness_Case_Study_at_Jordanian_Ministry_of_Interior-Jordan
39. Masa'deh, R. E., Obeidat, B. Y., \& Tarhini, A. (2016). A Jordanian empirical study of the associations among transformational leadership, transactional leadership, knowledge sharing, job performance, and firm performance: A structural equation modelling approach. Journal of Management Development, 35(5), 681-705. https://doi.org/10.1108/JMD-092015-0134

40. Nwachukwu, C., \& Chladkova, H. (2019). Firm resources, strategic analysis capability and strategic performance: organizational structure as moderator. International Journal for Quality Research, 13(1). Retrieved from https://www.mendeley.com/catalogue/f3cc861d-b689-31e5-b99e$1694 \mathrm{e} 7 \mathrm{a} 3265 \mathrm{~d} /$

41. Obeidat, A. (2019). IT Adaption with Knowledge Conversion Process (SECI). Management Science Letters, 9(13), 22412252. http://dx.doi.org/10.5267/j. msl.2019.7.029

42. Othman, A. E. A. (2009). Strategic HRM practices: Perspectives of Malaysian and Japanese owned companies in Malaysia. Global Business \& Management Research, 1(1), 1-22. Retrieved from https:// ir.unimas.my/id/eprint/7952/

43. Park, S. (2019). Cutbacks revisited: the relationship between resources and performance. Public Management Review, 21(4), 515536. https://doi.org/10.1080/14719 037.2018.1500631

44. Price, R. (2009). Following strategies less traveled. Industrial Engineer, 41(3), 36-39.

45. Ramanathan, T. T., \& Sharma, D. (2017). Multiple Classification Using SVM Based Multi Knowledge Based System. Procedia Computer Science, 115, 307-311. Retrieved from https:// www.researchgate.net/publication/320436962_Multiple_Classification_Using_SVM_Based_Multi_ Knowledge_Based_System

46. Ramataboe, L. T., \& Lues, L. (2018). Performance management implementation challenges in the Lesotho Ministry of Social 
Development. Journal for New Generation Sciences, 16(2), 76-91. Retrieved from https://journals. co.za/content/journal/10520/EJC$151 c 2 c 4927$

47. Robert, L. (2009). Management Fundamentals. Pre-press PMG.

48. Saffar, N., \& Obeidat, A. (2019). The effect of total quality management practices on employee performance: The moderating role of knowledge sharing. Management Science Letters, 10(1), 77-90. Retrieved from https://www.researchgate. net/publication/335220202_The_ effect_of_total_quality_management_practices_on_employee_performance_The_moderating_role_of_knowledge_sharing

49. Schmidt, J. A., Willness, C. R., Jones, D. A., \& Bourdage, J. S. (2018). Human resource management practices and voluntary turnover: a study of internal workforce and external labor market contingencies. The International Journal of Human Resource Management, 29(3), 571594. https://doi.org/10.1080/09585 192.2016.1165275

50. Shehadeh, R. M., Al-Zu’bi, Z., Abdallah, A. B., \& Maqableh, M. (2016). Investigating critical factors affecting the operational excellence of service firms in Jordan. Journal of Management Research, 8(1), 18-49.

51. Siebert, W. S., \& Zubanov, N. (2009). Searching for the optimal level of employee turnover: A study of a large UK retail organization. Academy of Management Journal, 52(2), 294313. Retrieved from https://journals.aom.org/doi/abs/10.5465/amj. 2009.37308149? journalCode=amj

52. Sloan, J. (2010). The Workforce Planning Imperative JSM.

53. Sthapit, A. (2008). Role of HRD in Successful Implementation of Organization Strategy: PYC. Nepal Journal of Management, 1(1), 67-82.

54. Suifan, T. S., Diab, H., \& Abdallah, A. B. (2017). Does organizational justice affect turnover-intention in a developing country? The mediating role of job satisfaction and organizational commitment. Journal of Management Development, 36(9), 1137-1148. Retrieved from https://www.researchgate. net/publication/319432631 Does_organizational_justice_affect_turnover-intention_in_a_developing_country_The_mediating role_of_job_satisfaction_and_organizational_commitment

55. Olson, E. M., Slater, S. F., \& Hult, G. T. M. (2011). The importance of structure and process to strategy implementation. Business Horizons, 48(1), 47-54. https://doi. org/10.1016/j.bushor.2004.10.002

56. Syedjavadin, S. R., \& Zadeh, M. H. (2009). HR Strategy and its aligning with Organizational Strategy and Human Capabilities. Iranian Journal of Management Studies, 2(2), 2-29. Retrieved from https://ijms.ut.ac.ir/article_23389 _2a21a7cf86ab779d6fedbf01ce3e e4cf.pdf

57. Täks, V., \& Vadi, M. (2019). Who and how do participate strategic planning? (No. 2019-03). Ordnungspolitische Diskurse.

58. Teo, S. T., \& Rodwell, J. (2003). HR Involvement, Strategic Integration and Performance of Public Sector HR Department in Australia. Academy of Management Proceedings, 1-6. Retrieved from https://researchers.mq.edu.au/ en/publications/hr-involvementstrategic-integration-and-performance-of-public-se

59. Thompson, J., \& Martin, F. (2010). Strategic Management: Awareness \& Change (6th ed.). South Western, Australia.

60. Vinces, J. J. Z. (2007). Individual Strategic Thinking as a Facilitator of Organizational Absorptive Capacity: An Examination of New Product Development Projects (Unpublished Doctoral Thesis). University of Ramon Liull, Barcelona, Spain. Retrieved from www.tesisenxarxa.net/TOX

61. Wattanasupachoke, T. (2009). Strategic Human Resource Management and Organizational Performance: A Study of Thai Enterprises. Journal of Global
Business, 3(2), 139-148. Retrieved from https://mydoctorate. wordpress.com/2009/10/05/ strategic-human-resourcemanagement-and-organizationalperformance-a-study-of-thaienterprises/

62. Werner, J. M., \& DeSimone, R. L. (2006). Human Resource Development. Ohio: Thomson South-Western.

63. Wheelen, T. L., \& Hunger, J. D. (2008). Strategic Management and Business Policy: Concepts \& Cases (11th ed.). New Jersey: PEARSON prentice Hall.

64. Wójcik-Karpacz, A., Karpacz, J., \& Ingram, M. (2015).

Entrepreneurial orientation as an object of exploration in strategic management118. Proceedings of MAC-EMM 2015 in Prague, 334. 